BADAN PENDIDIKAN DAN PELATIHAN KEUANGAN KEMENTERIAN KEUANGAN REPUBLIK INDONESIA
JURNAL BPPK

\title{
THE EFFECT OF FOREIGN DIRECT INVESTMENT ON TAX REVENUE IN DEVELOPING COUNTRIES
}

\author{
Arif Widya Pratomo \\ Faculty of Economics and Business, Universitas Indonesia \\ Erasmus University, The Netherland. Email: arifwepe@gmail.com
}

\section{ARTICLE INFORMATION}

ARTICLE HISTORY

Received

24 November 2019

Accepted to be published 30 Juni 2020

\section{KEYWORDS:}

FDI,

greenfiled,

brownfiled,

tax revenue,

endogeneity.

\begin{abstract}
Tujuan dari penelitian ini adalah untuk mempelajari pengaruh Foreign Direct Investment (FDI) terhadap penerimaan pajak di negara berkembang. Penelitian ini menggunakan FDI net inflow, FDI greenfield, dan FDI brownfield sebagai variabel bebas serta penerimaan pajak dengan beberapa jenis pajak sebagai variabel terikat. Menggunakan analisis data panel, penelitian ini menemukan bahwa di negara berkembang FDI net inflow berpengaruh positif terhadap penerimaan pajak secara keseluruhan, penerimaan pajak dari korporasi, penerimaan pajak dari Wajib Pajak orang pribadi, dan penerimaan pajak dari Pajak Pertambahan Nilai (PPN), namun tidak mempengaruhi penerimaan pajak dari kepemilikan properti. Selain itu, penelitian ini menyimpulkan bahwa FDI greenfield memiliki pengaruh positif terhadap penerimaan pajak, sementara FDI brownfield memiliki kecenderungan menurunkan penerimaan pajak. Untuk mengatasi kemungkinan adanya masalah endogenitas, penelitian ini menggunakan indeks "political stability and absence of violence" sebagai instrumental variable dan two-stage least square (2SLS) regression untuk mengestimasi parameter. Hasil regresi menunjukkan bahwa FDI net inflow memiliki pengaruh positif terhadap total penerimaan pajak tetapi tidak signifikan secara statistik. Namun demikian, hasil uji endogenitas menunjukkan bahwa tidak ditemukan adanya masalah endogenitas antara FDI dan penerimaan pajak. Sehingga dapat disimpulkan FDI dan penerimaan pajak memiliki kecenderungan hubungan satu arah yaitu FDI mempengaruhi penerimaan pajak.
\end{abstract}

The objective of this research paper is to study the effect of Foreign Direct Investment (FDI) on tax revenue in developing countries. FDI net inflow, greenfield, and brownfield FDI are selected as the independent variable. Tax revenue and its types are chosen as the dependent variable. Using panel data analysis, this research finds that FDI net inflow has a positive correlation on total tax revenue, corporate tax revenue, individual tax revenue, and VAT revenue. However, the effect of FDI net inflow on property tax revenue is not statistically significant. This research also finds that in the developing countries, the greenfield FDI has a beneficial effect on tax revenue while brownfield FDI tend to erode tax revenue. To deal with the possibility of endogeneity problems, this research uses "political stability and absence of violence" index as an instrumental variable and conducts a two-stage least square (2SLS) regression to estimate the parameter. The result shows that FDI has a positive correlation on total tax revenue, but not significant. However, the endogeneity test shows that the endogeneity problem is less likely to exist. To conclude, FDI and tax revenue tend to have only one direction effect from FDI to tax revenue.

\section{INTRODUCTION}

Since the early 1980s, the contribution of FDI in the development of developing countries has been increasing due to the lack of lending from commercial banks (Aitken and Harrison 1999: 605). As external funding, FDI can be seen as one of the solutions to fill the investment gap that is not covered by domestic saving. Many countries try to attract FDI by giving various incentives and minimize regulation that restricts FDI. However, attracting more FDI seem to have a "double-edged sword" effect on host countries.
On the one hand, FDI is not only as an external funding that fills the investment gap but also expected to bring a greater positive effect on the host country's economy through spillover effect (Demena and Bergeijk 2017:564). On the other side, there is a chance that the presence of the FDI erodes host country's productivity due to the uneven competition.

The policies regarding FDI are improving. Previously, the policy that related to FDI only focused on how to attract as much as possible FDI inflow to a host country by giving incentives. At present, the policy 
is also focusing on how FDI can bring a bigger benefit through the spillover effect for a host country. For example, by prioritizing the FDI in the manufacturing sector, joint venture formation, and increase the absorption level on a host country. Globally, trend of FDI inflow is still dominated by developed economies, followed by developing economies and transition economies (UNCTAD 2019). Therefore, there is a challenge for developing countries to attract more FDI with its possibility to bring positive or negative effect to their economy.

Recently, tax revenue has increasingly contributed to a larger share of GDP. There is a shift from countries that previously rely on non-tax revenue (natural resources, foreign aid) to taxes as main revenue. Low commodity prices lead many countries to broaden their tax bases. Taxes can be seen as "a financial blood supply" to the economy to finance government expenditures. The presence of FDI could support the role of taxes as a source of revenue. FDI could bring positive effect due to the bigger scale of an economy that might increase tax revenue capacity. The studies that have been done show that FDI positively affects tax revenue (Mahmood and Chaudhary 2013: 68, Aslam 2015: 250). However, aggressive tax incentives and transfer pricing motivation might deteriorate tax revenue performance. Moreover, among the various types of incentives, the tax incentive is the most preferable for a host country to attract FDI (UNCTAD 2018: 151). The study that has been done in Ethiopia shows that FDI negatively affects tax revenue due to massive tax incentives (Jeza et al. 2016: 171).

Considering the increase of FDI's role in economic development and the increase of tax's role as the main source of government revenue, encourages author to explore whether the presence of FDI could elevate tax revenue. This research is also motivated by previous researches which mostly focuses on the tax as a regulatory function to promote FDI. The study that has been done show that a lower tax rate might attract more FDI (Cassou 1997: 1295). Moreover, the empirical evidence or research that investigates on the effect of FDI on tax revenue remains rare, for example: the effect of FDI on tax revenue at country-level in OECD countries (Bayar and Ozturk 2018: 38); in Pakistan (Mahmood and Chaudhary 2013: 68); in Ethiopia (Jeza et al. 2016: 171); in Sri Lanka (Aslam 2015: 250); and the effect of FDI on tax revenue at firm level in Turkey (Balıkçıoğlu et al. 2016: 780).

The purpose of this research is to analyze the relationship between FDI and tax revenue. This research wishes to address the main question: what is the effect of FDI on tax revenue? This research paper is also expected to extend previous findings of the effect of FDI on tax revenue. This research paper could be the first empirical study that investigates the impact of FDI on tax revenue that uses several types of FDI, such as FDI net inflow, greenfield and brownfield FDI, and several types of tax revenue such as total tax revenue, corporate tax revenue, individual tax revenue, VAT revenue, and property tax revenue.

Investigating the effect of FDI on tax revenue is also projected to have an essential contribution to the policy formulation. If the result shows that FDI positively affects tax revenue, the government can maintain the FDI promotion policy. However, if FDI has a negative effect on tax revenue performance, the government should formulate policies to avoid tax revenue degradation due to the presence of FDI, otherwise the government should consider gradually limiting FDI by reducing the incentives given to foreign investors. This research is also expected to show which type of tax that not affected by FDI.

This research paper is divided into five sections. Section 1 is the introduction. This section provides the background of the study. Section 2 will provide the literature review and hypothesis. Section 3 will provide empirical model, and methodology. Results and findings will be delivered in section 4 and followed by conclusion in section 5 .

\section{LITERATURE REVIEW AND HYPOTHESIS}

\subsection{The role of FDI on economic growth}

Theoretically, the Harrold-Domar growth model posits that economic growth can be achieved from an investment that is acquired from saving at a linear movement. In this theory, economic growth is expected to increase along with the increase of saving. Solow improved this theory. He defines economic growth $(Y)$ as a function of capital $(K)$ and workforce $(L)$ (Solow 1956). Under this theory, economic growth can be achieved from capital accumulation. The accumulation of capital will increase due to investment from saving and decrease due to depreciation and population growth. Since the level of investment is still determined by the level of saving, low in saving rate will lead to lower economic growth. In this case, FDI is expected to directly fill the gap between domestic savings and actual investment needs to achieve expected economic growth.

Solow growth model considers technology as a pivotal factor to induce economic growth. In his model, technological progress is categorized as an exogenous variable. On the other hand, Romer introduces a growth theory that treats technological progress as an endogenous variable (Romer 1990). Under this model, technological progress is generated through the production process. Learning by doing in the production process improves human capital accumulation that in turn, will improve technological progress. In addition, Romer also argues that the spillover effect from developed countries also generates a knowledge accumulation that important for technological progress. The spillover of technology can be obtained from developed countries through FDI (Zhu 2010: 178). FDI can be seen as one of the channels of technological progress (Romer 1990). FDI brings not 
only capital stock but also technology and managerial skill that benefit economic growth (Almfraji and Almsafir 2014: 207). Therefore, besides the direct effect of FDI to economic growth through capital accumulation, FDI is projected to indirectly stimulate economic development through a spillover effect on the economy of the host country.

\subsection{How does FDI affect taxation?}

One of the variables that could be affected by FDI in the host country is tax revenue. FDI could affect tax revenue positively or negatively. There are several channels of FDI directly affect tax revenue positively. First, a direct positive effect of FDI on tax revenue is revealed if the presence of FDI is followed by the establishment of a new multinational company (MNC). A new MNC will be registered as a new taxpayer. In this sense, the more taxpayers, the more potential amount of tax paid to the government as well. Second, the direct effect of FDI on tax revenue is also can be caused by the transfer of technology, knowledge and managerial skill from the backward spillover effect from the parent company in a home country to MNC as its subsidiary in a host country. The parent company might transfer knowledge, technology and managerial skill through training that is given to the selected supplier who fulfils initial qualifications to learn about multinational systems such as quality control, inventory and cost accounting (Blalock and Gertler 2005: 79). As a result, tax revenue might increase due to the increase of MNCs' profitability (MacDougall 1960: 208).

The positive and indirect effect of FDI on tax revenue occurs if tax revenue increases due to the larger scale of economies that are caused by horizontal spillover effects. The effect of FDI on tax revenue depends on the competition and spillovers of technology carried by MNCs that stimulate productivity (Nguyen et al. 2014: 28). Productivity spillover might occur when output increases due to technological transfer from MNCs to a domestic company. The atmosphere of competition also encourages domestic companies to adopt technology or knowledge to increase their productivity and efficiency (Demena and Bergeijk 2019). Domestic companies observe and imitate the knowledge or technology that is used by the foreign company to increase their productivity. The movement of trained labour from MNCs to a domestic company also could stimulate the increase in productivity in a domestic company. Furthermore, the presence of FDI might trigger the increase in the number of domestic-own companies to support the operations of MNCs. In other words, every addition of FDI might stimulate the "crowding-in" effect for the host country (Borensztein et al. 1998: 117). Increasing the number of companies means increasing the number of taxpayers. Moreover, an increase in some domestic companies will be followed by the rise in labour demand. It implies that FDI also has a role in reducing the unemployment rate (Zeb et al. 2014: 15). Therefore, the increase in productivity, the increase in the number of companies, and the increase of employment would increase the tax paid to the government.

The presence of FDI might increase international trade from the host country to the home country (customer-supplier relationships) due to the increase of imports of intermediate goods from the home country, and the increase of exports from final good products from host country (Safitriani 2014: 98). Therefore, the tax revenue that related to international trade might increase as well.

In addition, since FDI tends to affect economic growth and level of income positively, the increase in FDI might trigger the rise in the aggregate demand that might support the government to collect more taxes (Mahmood and Chaudhary 2013: 59), for example, value-added tax, property tax and the other types of indirect tax.

The presence of the FDI also might erode tax revenue directly. Competition by lowering the tax rate to attract FDI is one of the reasons why FDI might decrease tax revenue (MacDougall 1960: 280, Nguyen et al. 2014: 28). Furthermore, the presence of FDI might negatively affect tax revenue directly if there is a "transfer pricing" motive from MNCs (Gropp and Kostial 2000: 1). The globalization and the significant differences in tax rate among countries create opportunities for MNCs to do profit shifting. As a result, the host country might not get the optimum tax revenue advantage from FDI, if the profit from MNCs is shifted to other countries that have a lower tax rate or tax heaven countries.

FDI might also bring a negative indirect effect on tax revenue. Competition between MNCs and domestic companies could shrink domestic company contribution to the economy. This is because, the domestic company commonly experience a lack of technology, knowledge, and managerial skill that's why domestic companies tend to less productive compared to MNCs. Furthermore, the implementation of intellectual property right (IP) restricts a domestic company to catch-up with technological progress that is achieved by MNCs. As a result, the presence of FDI potentially to have a "crowding-out" effect for a domestic company. "Crowding-out" effect also might occur if MNCs easily recruit talented employees from the domestic company. The higher salary that is given by MNCs might stimulate talented employees to move to MNCs and prevent the domestic company from hiring talented employees (Long 2005: 333). This situation is worsened if there is an industrial monopoly from MNCs that avoid domestic companies to compete. As a result, the tax revenue contribution from the domestic company will decline due to uneven competition (Nguyen et al. 2014: 28).

\subsection{Empirical evidence of the effect of FDI on tax revenue}

Research conducted by Mahmood and Chaudhary (2013: 68) at the country-level using time series data 
from 1972 to 2010 in Pakistan concluded that an increase in FDI inflows would be followed by an increase in tax revenue (both as a percentage of GDP). To investigate the short run and the long-run relationship between the dependent variable and independent variable, they use the Auto Regressive Distributive Lag (ARDL) and Error Correction Model (ECM). The study that has been done at the countrylevel using time series data from 1990 to 2013 in Sri Lanka also posit that FDI has a positive contribution to tax revenue (Aslam 2015: 250). The causality test concludes that there is a one-way direction from FDI to tax revenue. Furthermore, the research at the countrylevel using panel data from 1996 to 2012 of European Transition Economy countries conclude that FDI inflow stimulates tax revenue (Odabaş 2016: 22). The result also shows that there is a single causality from FDI inflow to tax revenue.

In contrast, the study at the country level that had been done in Ethiopia shows that the impact of FDI on tax revenue mostly negative (Jeza et al. 2016: 171). The study uses time series data from 1974-2014 to study the impact of FDI to tax revenue in aggregate form and disaggregate form (based on the type of tax). They use tax revenue as the dependent variable and FDI net inflows (both as a percentage of GDP) as an independent variable. Using ADRL and ECM, the result shows that at the aggregate level, the effect of FDI inflow to tax revenue is negative and significant. In the disaggregated level, FDI also harms several types of taxes, such as indirect tax, corporate income tax, and personal income tax. However, the effect of FDI inflow to trade tax revenue is positively significant.

On the other hand, study at the country level that has been conducted in OECD countries found that the effect of FDI on tax revenue has a mixed result (Bayar and Ozturk 2018: 38). Using a causality test and panelcointegration test, the research found that there is a one-way causality effect from FDI inflow to total tax revenue. However, there is no significant effect of FDI inflow on total tax revenue at the panel level. On the other hand, if the test is conducted for every OECD country, the results are varied. FDI gives benefits on tax revenue in the United States, United Kingdom, Iceland, and Sweden. Conversely, the presence of FDI erodes tax revenue in Austria, Italy, Poland, and France.

From the existing empirical evidence, can be summarized that the research of the effect of FDI on tax revenue are still limited and inconclusive. Even though several studies use the difference econometric and methodological approach, the difference sample and period, the result still shows that FDI might positively or negatively affect tax revenue. The only convergence result from the previous studies is that FDI and tax revenue only have one-way direction causality from FDI to tax revenue. Therefore, to extend previous research, the effect of FDI on tax revenue in developing countries will be tested using several types of FDI (FDI net inflow, greenfield FDI, and brownfield FDI), and several types of taxes. To provide more information, this study will also compare the regression result from developing countries, high-income countries, and all sample.

\section{RESEARCH METHODOLOGY}

This research uses secondary data at the country level that cover up to 80 countries over the period 2000 until 2016. Data of FDI net inflow was collected from the open data of the World Bank. The greenfield and the brownfield FDI data were collected from the UNCTAD, and data on tax revenue were obtained from the OECD. Several data of control variables such as GDP percapita, the share of agriculture in GDP, international trade, consumer price index, and the indicator of financial development were also collected from the World Bank. Data corruption Perception Index as the proxy of government quality was obtained from the website of Transparency International. In this research, countries are classified into two groups highincome and developing countries based on income classification.

\subsection{Empirical model}

Empirical model is adopted and modified from previous research that investigate tax revenue determinant (Castro and Camarillo 2014: 40, Chelliah et al. 1975: 204) and the research on the effect of liberalization on tax performance (Gaalya 2015: 235). This research paper suggested the following empirical model:

TaxRevenue $_{i t}=\alpha_{i}+\beta_{1} F D I_{i t}+\beta_{2} \operatorname{lnGDPPC} C_{i t}+$ $\beta_{3} T R A D E_{i t}+\beta_{4} A G R I_{-} G D P_{i t}+\beta_{5} C P I_{i t}+$ $\beta_{6}\left(F D I_{i t} * \ln G D P P C_{i t}\right)+\beta_{7} I N F L_{i t}+\beta_{8} P C B_{i t}+$ $\varepsilon_{i t}$

This research uses tax revenue as the dependent variable. Tax revenue will be divided into several types of taxes, such as total tax revenue, corporate tax revenue, individual tax revenue, VAT revenue, and property tax revenue. By disaggregating tax revenue into several types of taxes, the impact of FDI will be more detailed. This is because various types of taxes may differ in response to the presence of FDI.

This research uses FDI net inflow, greenfield and brownfield FDI as independent variables. In general, there are two types of FDI based on how it comes into the host country. First, a parent company in a home country establishes a new subsidiary company in a host country. This activity includes building a production facility and office in a host country - this type of FDI named as a "greenfield" FDI. The second type of FDI flows into the host country through mergers with existing domestic companies or by acquiring ownership of domestic companies (the increase in the share of foreign investor ownership). This type of FDI named as a "brownfield" or "Merger and Acquisition (M\&A)" FDI. So far, research about FDI on tax revenue have never concluded which type of FDI that has a higher effect on tax revenue, whether it is greenfield or brownfield FDI. The greenfield FDI and brownfield FDI might have different effects on tax revenue. The 
establishment of greenfield FDI could be more expensive than brownfield FDI. This is due to the establishment of greenfield FDI (for example, new factories) must be started from the establishment of physical and non-physical installations. As a result, high costs erode corporate profits that in turn will reduce taxes to be paid to the government. Moreover, greenfield FDI will take a longer period to generate taxable income if there is compensation for losses brought to the following year. However, greenfield FDI might bring a positive effect on tax revenue. The increase in taxpayer number due to the company establishment and reducing unemployment might elevate the income of the country that eventually will increase tax revenue.

This research uses several control variables based on previous studies such as GDP per-capita (Gupta 2007: 31, Mahmood and Chaudhary 2013: 68), international trade (Leuthold 1991: 184), the share of agriculture in GDP (Castro and Camarillo 2014: 35, and Gupta 2007:11), corruption (Rosid et al. 2016: 387 and Friedman et al. 2000: 459), inflation (Gaalya 2015: 237), and bank credits to the private sector in the portion of GDP as a proxy for development in the financial sector (Ebi 2018: 93).

\subsection{Methodology}

This research uses a panel data analysis to examine the effect of FDI on tax revenue with the assumption that FDI and tax revenue only have oneway causality (from FDI to tax revenue) and free from the endogeneity problem. The reasons behind the selection of this methodology are based on theoretical frameworks that FDI could affect tax revenue directly or indirectly through the spillover effect. The method selection was strengthened by the empirical evidences from the previous studies that conclude that FDI and tax revenue only have one-way causality from FDI to tax revenue (Aslam 2015: 250, Bayar and Ozturk 2018: 38, Odabaş 2016: 22). On the other hand, there is also a possibility of two-way causality or reverse causality from tax revenue to FDI. There are two possible channels on how FDI is affected by tax revenue. Firstly, since the tax revenue is the result from the multiplication between the tax rate and the tax base, given the tax base and other variables are constant, tax revenue will depend on the tax rate only. The low tax rate will attract more investment. Studies on the impact of the tax rate and FDI conclude that the domestic tax rate has a negative and significant impact on FDI (Cassou 1997: 1295). However, given all the things constant, the low tax rate means a lower tax revenue as well. Secondly, tax revenue is one of the economy's indices. The high tax revenue indicates the bigger size of the market and economy, good infrastructure, and good public administration. These conditions are demanded by investors as a necessary condition to make an investment decision. Therefore, besides FDI could increase the tax revenue, tax revenue might also attract the FDI as well. In addition, the endogeneity problem might also emerge if there is an omitted variable that possibly affects both the independent and dependent variable (the error term).

The endogeneity problem causes the regression obtained a bias and inconsistent parameter estimator $(\beta)$. One of the methods to solve the endogeneity problem is by choosing the Instrumental Variable (IV) that has a correlation with the independent variable (endogenous variable) but does not directly affect the dependent variable. Two-stage least square regression (2SLS) can be used to estimate the parameter in the model that is suspected has an endogeneity problem (Nachrowi and Usman 2006: 275, Wooldridge 2015). However, this method faces a challenge because the IV is hard to find. Moreover, there is no ideal IV for FDI (Borensztein et al. 1998: 133). Therefore, many research only acknowledge that there is a possibility endogeneity problem without trying to solve the problem.

This research paper will also discuss if there is an assumption that there might be an endogeneity problem between FDI and tax revenue. This research tries to solve the endogeneity problem by selecting Instrumental Variable (IV) and use two-stage least square (2SLS) regression to estimate the parameter. By adopting and modifying IV selection in the research that has been done by Lensink and Morrissey (2001: 15), this research paper uses the index of "Political stability and absence of violence" (POLSTAB) from the World Governance Indicators (WGI) as an IV. POLSTAB is an indicator reflecting the perception of political instability as a result of a country's unconstitutional process, violence and terrorism. The perception of the political environment is expected to affect investment decision but does not directly affect tax revenue. The perception of the political climate is considered as an essential factor by investors to make an investment decision.

This research modified the equation (1) as the structural model without interaction variable, as follows:

$T A X R E V_{G D P i t}=\sigma_{i}+\delta_{11} F D I_{i t}+\delta_{12} \ln G D P P C_{i t}+$ $\delta_{13} T R A D E_{i t}+\delta_{14} A G R I_{G D P i t}+\delta_{15} C P I_{i t}+$ $\delta_{16} I N F L_{i t}+\delta_{17} P C B_{i t}+\varepsilon_{i t}$

The reduced model is developed with the assumption that FDI is the only endogenous variable in the right-hand side of the structural model, as follows:

$$
\begin{aligned}
& F D I_{i t}=\omega_{i}+\gamma_{21} P O L S T A B_{i t}+\gamma_{22} \ln G D P P C_{i t}+ \\
& \gamma_{23} T_{R A D E_{i t}}+\gamma_{24} A G R I_{G D P}+\gamma_{25} C_{i t} P I_{i t}+ \\
& \gamma_{26} I N F L_{i t}+\gamma_{27} P C B_{i t}+\varepsilon_{i t}
\end{aligned}
$$

\section{RESULTS AND FINDINGS}

The analysis was started with Fixed Effect Model (FEM) of panel data and followed by 2SLS regression. Preliminary tests related to the multicollinearity issue have been conducted to ensure that regression provides the unbiased estimators. 


\subsection{The regression results of the FDI net inflow on tax revenue as percentage of GDP}

The regression results of the FDI net inflow on tax revenue are presented in the table 1 . In the group of all countries, FDI net inflow has a positive impact and statistically significant on government revenue from corporate tax, individual tax, and VAT, but negatively affects revenue from property tax. In high-income economies, FDI brings a significant and negative effect on total tax revenue and property tax revenue. On the other hand, in developing countries, the effect of FDI on government revenue from taxes statistically meet the expectation that the presence of FDI is associated with the rise in all types of tax revenue except property tax revenue.

Table 1 Regression result of FDI and tax revenue as percentage of GDP (equation 1)

\begin{tabular}{|c|c|c|c|c|c|c|c|c|c|}
\hline Group & No & $\begin{array}{l}\text { Dependent } \\
\text { Variables }\end{array}$ & Model & $\begin{array}{l}\text { FDINET } \\
\text { IN_GDP }\end{array}$ & $\begin{array}{c}\text { Interaction } \\
\text { variable }\end{array}$ & $\begin{array}{c}\text { Control } \\
\text { Var+ }\end{array}$ & Obs & $\mathrm{R}^{2}$ & $\begin{array}{l}\text { Number of } \\
\text { countries }\end{array}$ \\
\hline (1) & $(2)$ & (3) & (4) & (5) & (6) & (7) & (8) & (9) & (10) \\
\hline \multirow{5}{*}{ 恶点 } & 1. & TAXREV_GDP & FEM & 0.005 & 0.000 & YES & 1,208 & $16 \%$ & 80 \\
\hline & 2. & CORPTAX_GDP & FEM & $0.010^{* *}$ & $-0.001^{*}$ & YES & 1,146 & $8 \%$ & 75 \\
\hline & 3. & INDTAX_GDP & FEM & $0.007^{* *}$ & -0.000 & YES & 1,144 & $4 \%$ & 75 \\
\hline & 4. & VAT_GDP & FEM & $0.007^{* *}$ & -0.000 & YES & 1,176 & $16 \%$ & 78 \\
\hline & 5. & PROPTAX_GDP & FEM & $-0.023^{* * *}$ & $0.002^{* * *}$ & YES & 1,166 & $13 \%$ & 78 \\
\hline \multirow{5}{*}{ 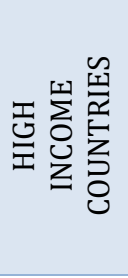 } & 1. & TAXREV_GDP & FEM & $-0.019 *$ & $0.003^{* * *}$ & YES & 591 & $7 \%$ & 39 \\
\hline & 2. & CORPTAX_GDP & FEM & 0.003 & -0.000 & YES & 585 & $11 \%$ & 38 \\
\hline & 3. & INDTAX_GDP & FEM & 0.007 & -0.000 & YES & 585 & $4 \%$ & 38 \\
\hline & 4. & VAT_GDP & FEM & 0.000 & 0.000 & YES & 581 & $7 \%$ & 38 \\
\hline & 5. & PROPTAX_GDP & FEM & $-0.034^{* * *}$ & $0.003^{* * *}$ & YES & 591 & $19 \%$ & 39 \\
\hline \multirow{5}{*}{ 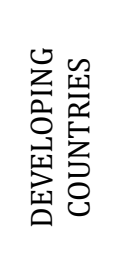 } & 1. & TAXREV_GDP & FEM & $0.052^{* *}$ & $-0.003^{*}$ & YES & 610 & $47 \%$ & 40 \\
\hline & 2. & CORPTAX_GDP & FEM & $0.035^{* *}$ & -0.001 & YES & 561 & $36 \%$ & 37 \\
\hline & 3. & INDTAX_GDP & FEM & $0.012^{*}$ & -0.000 & YES & 559 & $18 \%$ & 37 \\
\hline & 4. & VAT_GDP & FEM & $0.037^{* * *}$ & -0.000 & YES & 588 & $32 \%$ & 39 \\
\hline & 5. & PROPTAX_GDP & FEM & 0.002 & -0.000 & YES & 568 & $10 \%$ & 38 \\
\hline
\end{tabular}

$* * * \mathrm{p}<0.01, * * \mathrm{p}<0.05,{ }^{*} \mathrm{p}<0.1$

+ presented in appendix

Source: Author's calculation

Although the evidence shows that the impact of FDI on tax revenue is mostly statistically significant to increase tax revenue, the effect is relatively small. In developing countries, every one percent rise in FDI net inflow (as a percentage of GDP) will increase total tax revenue 0.052 percent of GDP, corporate tax revenue 0.035 percent of GDP, and VAT revenue 0.037 percent of GDP. The smallest positive effect of FDI net inflow is received by individual tax revenue. Every one percent increase in FDI net inflow only increases individual tax revenue about 0.012 percent of GDP. The positive impact of FDI on total tax revenue confirms the result from the previous research that have been done by Aslam (2015: 250), Odabaş (2016: 22), and Mahmood and Chaudhary (2013: 68). On the other hand, FDI does not has a significant influence on property tax revenue. This might be caused by property tax only have a small contribution in total tax revenue. Moreover, nowadays, the economy gradually shifts from property-based to service-based due to the development of information and technology (Augustine 2009: 2).

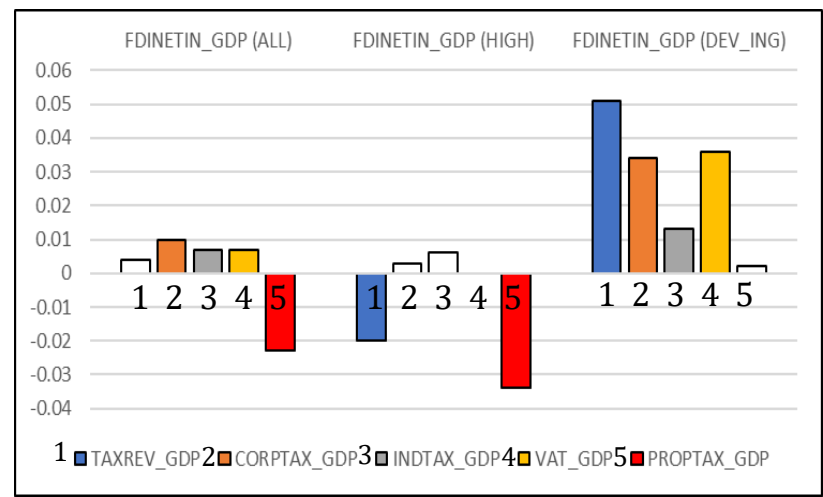

*The insignificant coefficients are presented in the colourless (unshaded) bar chart.

\section{Figure 1 Graph of FDI coefficient on tax revenue} as a percentage of GDP

As depicted in Figure 1, there is a different effect of FDI net inflow on total tax revenue (bar 1) in highincome countries and developing countries. FDI net inflow in high-income countries bring a negative effect on total tax revenue. While in developing countries most of FDI net inflow brings advantages for several types of tax revenue. 
The high-income countries might have more FDI outflow compare to developing countries. As a result, FDI net inflow from high-income countries might be decreasing due to FDI outflow to other country. The negative effect of FDI in the high-income countries confirms the finding from the research at the panel level that have been done by Castro and Camarillo (2014: 35) and Bayar and Ozturk (2018: 38). Moreover, FDI net inflow from high-income countries seems does not have any impact on corporate tax revenue, individual tax revenue, and also VAT revenue.
The regression result from the effect of interaction variable between FDI net inflow and GDP per-capita on tax revenue are presented in Table 1 column (6). The coefficients of the interaction variable mostly show an insignificant effect. This means the effect of FDI does not depend on the level of GDP per-capita. However, the negative and significant sign of the interaction variable should be note even it is small. This is because, the positive effect of FDI might be decreasing along with the increase of GDP per-capita or FDI.

Table 2 The coefficient of the greenfield and brownfield FDI on tax revenue

\begin{tabular}{|c|c|c|c|c|c|c|c|}
\hline Group & No & $\begin{array}{l}\text { Dependent } \\
\text { Variables }\end{array}$ & Model & $\begin{array}{l}\text { Greenfield } \\
\text { FDI_GDP }\end{array}$ & $\begin{array}{l}\text { Interaction } \\
\text { variable } \\
\text { FDI and } \\
\text { GDPPC }\end{array}$ & $\begin{array}{l}\text { Brownfield } \\
\text { FDI_GDP }\end{array}$ & $\begin{array}{c}\text { Interaction } \\
\text { variable } \\
\text { FDI and GDPPC }\end{array}$ \\
\hline (1) & (2) & (3) & (4) & (5) & (6) & (7) & (8) \\
\hline \multirow{5}{*}{ 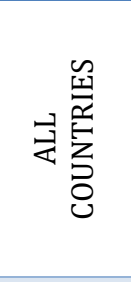 } & 1. & TAXREV_GDP & FEM & $16.614^{* *}$ & $-1.932^{* *}$ & $39.879^{* *}$ & $-3.937^{* *}$ \\
\hline & 2. & CORPTAX_GDP & FEM & 0.740 & -0.015 & $15.671^{*}$ & $-1.541^{*}$ \\
\hline & 3. & INDTAX_GDP & FEM & $18.116^{* * *}$ & $-1.828^{* * *}$ & 7.006 & -0.581 \\
\hline & 4. & VAT_GDP & FEM & -0.575 & 0.077 & 0.465 & -0.171 \\
\hline & 5. & PROPTAX_GDP & FEM & 1.346 & -0.160 & -0.661 & 0.055 \\
\hline \multirow{5}{*}{ 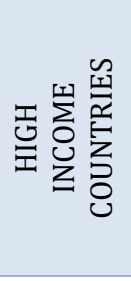 } & 1. & TAXREV_GDP & FEM & 5.103 & -1.136 & $38.404^{* *}$ & $-3.698^{* *}$ \\
\hline & 2. & CORPTAX_GDP & FEM & $-37.115^{* * *}$ & $3.467^{* *}$ & 11.469 & -1.126 \\
\hline & 3. & INDTAX_GDP & FEM & $31.772^{* *}$ & $-3.464^{* *}$ & 10.737 & -0.910 \\
\hline & 4. & VAT_GDP & FEM & 12.672 & -1.149 & 0.657 & -0.153 \\
\hline & 5. & PROPTAX_GDP & FEM & 8.733 & -1.014 & 0.113 & -0.006 \\
\hline \multirow{5}{*}{ 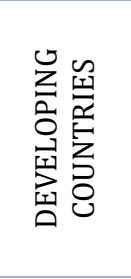 } & 1. & TAXREV_GDP & FEM & $14.782^{* *}$ & $-1.733^{* *}$ & -8.555 & 1.299 \\
\hline & 2. & CORPTAX_GDP & FEM & 4.496 & -0.470 & 43.710 & -4.302 \\
\hline & 3. & INDTAX_GDP & FEM & $16.948^{* * *}$ & $-1.687^{* * *}$ & $-57.835^{* *}$ & $6.291^{* *}$ \\
\hline & 4. & VAT_GDP & FEM & -1.078 & 0.129 & -11.620 & 0.937 \\
\hline & 5. & PROPTAX_GDP & FEM & -0.046 & 0.004 & -14.661 & 1.471 \\
\hline
\end{tabular}

$* * * \mathrm{p}<0.01, * * \mathrm{p}<0.05, * \mathrm{p}<0.1$

Source: Author's calculation

\subsection{The regression result of the greenfield and brownfield FDI on tax revenue}

The regression results of the greenfield FDI are presented in Table 2 column (5). For all samples, the greenfield FDI statistically brings a beneficial effect on total tax revenue and individual tax revenue. However, in the high-income economies, the greenfield FDI has a mixed result, greenfield FDI positively affects individual tax revenue, but negatively affects corporate tax revenue. While, in developing countries, the greenfield FDI statistically has a significant and positive effect on total tax revenue and individual tax revenue. This might be caused by establishing a new investment in developing countries is cheaper compare to in highincome countries. Moreover, establishing a new investment in developing countries will increase the number of taxpayers and reduce unemployment that in the end will give advantages on tax revenue.
The results of the regression between brownfield FDI as a percentage of GDP on tax revenue are presented in Table 2 column (7). For whole samples, brownfield FDI statistically brings a benefit on total tax revenue and corporate tax revenue. In high-income economies, brownfield FDI has a beneficial effect only on total tax revenue. While in developing countries, brownfield FDI statistically deteriorate individual tax revenue. This effect might be caused by merger and acquisition process tend to be followed by the improvement process for managerial and efficiency of the production process. Implementing a higher standard for employee and automation might replace a manual process that in turn would decrease individual income and individual tax revenue as well. The similar results emerge when brownfield FDI is measured in percapita form. 
The coefficients of interaction variable between FDI (greenfield and brownfield) and GDP per-capita are presented in Table 2 column (6) and (8). In highincome countries, the coefficients of interaction variable between greenfield FDI and GDP per-capita show a mixed result. While in developing countries, interaction variable shows a negative coefficient and statistically significant for total tax revenue and individual tax revenue. The negative sign of interaction between greenfield FDI and GDP percapita should be noted. This is because, if we hold per-capita income in developing countries constant, any additional FDI will increase tax revenue, but this effect is decreasing along with the increase of FDI. On the other hand, most of the coefficient of interaction variable between brownfield FDI and GDP per-capita on tax revenue show an insignificant effect.

This research also confirms that the proportion of agriculture in GDP and GDP per-capita are the predictor for tax revenue in all samples' groups, while the other control variables have a mixed result as shown in appendix 1 and 2 .

\subsection{The treatment of the endogeneity problem}

Adopting instrumental variable (IV) that has been used by Lensink and Morrissey (2001: 15), this research uses one of the world governance indicators as IV named "Political stability and absence of violence" (POLSTAB) and 2SLS regression. POLSTAB is an index range from -2.5 to 2.5 , where the former shows unfavorable condition and the letter shows favorable condition for investment. As an IV, POLSTAB should have a correlation with the suspected endogenous variable (FDI), but do not have a direct correlation with tax revenue. To examine this condition, this research conducts the first stage regression using the reduced model (equation 3). As shown in Table 3 column (1), (2), and (3), the first stage regression concludes that POLSTAB significantly affects FDI for the whole samples, high-income countries, and developing countries. In other words, POLSTAB is statistically meet the basic condition as an IV of FDI in three different groups of observation. At the first stage, the predicted value of FDI (FDIhat) can be obtained in order to conduct regression in the second stage. Error term in the first stage is also needed to conduct the endogeneity test in the further process.

Table 3 First stage, instrumental variable regression result

\begin{tabular}{|l|c|c|c|}
\hline & Whole sample & High-income & Developing countries \\
\hline VARIABLES & $(1)$ & $(2)$ & $(3)$ \\
\hline POLSTAB & FDINETIN_GDP & FDINETIN_GDP & FDINETIN_GDP \\
\hline & $4.378^{* *}$ & $9.653^{* *}$ & $1.392^{* *}$ \\
\hline Control Variables & $(2.059)$ & $(4.543)$ & $(0.652)$ \\
\hline Observations & YES & YES & YES \\
\hline R-squared & 1,234 & 591 & 636 \\
\hline Number of country1 & 0.014 & 0.023 & 0.069 \\
\hline
\end{tabular}

*** $\mathrm{p}<0.01,{ }^{* *} \mathrm{p}<0.05,{ }^{*} \mathrm{p}<0.1$, Standard errors in parentheses

Source: Author's calculation

Table 4 Second stage, and endogeneity test

\begin{tabular}{|c|c|c|c|c|c|c|}
\hline & \multicolumn{2}{|c|}{ Whole sample } & \multicolumn{2}{|c|}{ High-income } & \multicolumn{2}{|c|}{ Developing-countries } \\
\hline & (1) & (2) & (3) & (4) & (5) & $(6)$ \\
\hline VARIABLES & $\begin{array}{c}\text { TAX } \\
\text { REV_GDP }\end{array}$ & $\begin{array}{c}\text { TAX } \\
\text { REV_GDP }\end{array}$ & $\begin{array}{c}\text { TAX } \\
\text { REV_GDP }\end{array}$ & $\begin{array}{c}\text { TAX } \\
\text { REV_GDP }\end{array}$ & $\begin{array}{c}\text { TAX } \\
\text { REV_GDP }\end{array}$ & $\begin{array}{c}\text { TAX } \\
\text { REV_GDP }\end{array}$ \\
\hline \multirow[t]{2}{*}{ FDINETIN_GDP } & & 6.369 & & 0.270 & & 0.229 \\
\hline & & $(8.020)$ & & $(0.191)$ & & $(0.515)$ \\
\hline \multirow[t]{2}{*}{$\begin{array}{l}\text { FDIhat } \\
\text { (Predicted in the 1st stage) }\end{array}$} & 6.082 & & 0.255 & & 0.237 & \\
\hline & $(7.996)$ & & $(0.189)$ & & $(0.517)$ & \\
\hline \multirow[t]{2}{*}{$\begin{array}{l}\text { Error } \\
\text { (Predicted in the 1st stage) }\end{array}$} & & -6.363 & & -0.265 & & -0.176 \\
\hline & & $(8.020)$ & & $(0.192)$ & & $(0.516)$ \\
\hline Control Variables & YES & YES & YES & YES & YES & YES \\
\hline Observations & 1,229 & 1,225 & 595 & 591 & 627 & 627 \\
\hline R-squared & 0.157 & 0.159 & 0.059 & 0.061 & 0.459 & 0.464 \\
\hline Number of country1 & 81 & 81 & 39 & 39 & 41 & 41 \\
\hline
\end{tabular}

${ }^{* * *} \mathrm{p}<0.01,{ }^{* *} \mathrm{p}<0.05,{ }^{*} \mathrm{p}<0.1$, Standard errors in parentheses

Source: Author's calculation 
The second stage regression aims to estimate the parameter of the estimated endogenous variable (FDIhat) using the structural model in the equation (2). As shown in Table 4 column (1), (3), and (5), the results of the second stage regression show that predicted FDI (FDIhat) positively affects tax revenue in all sample groups, but the effect is not statistically significant.

However, the results from endogeneity test using predicted error term (omitted variables of FDI from the first stage regression) indicate that error term has an insignificant effect on the total tax revenue, as shown in Table 4 column (2), (4), and (6). In other words, there are no omitted variable of FDI in the first stage regression. Therefore, the endogeneity problem in this research is less likely to exist. This finding is consistent with previous research that have been done by Bayar and Ozturk (2018: 38), Odabaş (2016: 22), and Aslam (2015: 250). Their researches conclude that FDI and tax revenue only have a single direction effect from FDI to tax revenue. This finding also confirms that data analysis in the previous subsection using the panel data method with the assumption of one-way causality from FDI to tax revenue is acceptable.

\section{CONCLUSIONS}

This research paper has discussed the effect of FDI on tax revenue by exploring the possible channels on how FDI could affect tax revenue and examining the effect using econometric tools. The regression results show that in developing countries FDI has a positive effect and statistically significant on total tax revenue, corporate tax revenue, individual tax revenue, and VAT revenue, but it has no effect on property tax revenue. However, the real effect of FDI on tax revenue is relatively small. This information was obtained from the regression result that shows a small coefficient.

This research finds that in developing countries, the greenfield FDI is a better choice to increase tax revenue rather than brownfield FDI. In contrast, in high-income countries, the brownfield FDI is better than greenfield FDI to elevate tax revenue. However, the coefficient of the interaction variable between GDP per-capita and greenfield FDI in developing countries show a negative sign. In other words, the effect of greenfield FDI on tax revenue in developing countries is increasing, but this effect is decreasing (increasing at decreasing rate) along with the increase of GDP per-capita or greenfield FDI.

To deal with the endogeneity problems, this study has chosen political stability and the absence of violence (POLSTAB) as an instrumental variable (IV). The results of the two-stage least square (2SLS) regression show that FDI positively affects total tax revenue, but the effect is not significant. However, endogeneity tests prove that the endogeneity problem is less likely to exist.
This research has limitations. First, data collection and sample selection are conducted based on the availability of the data, especially tax revenue data and unbalance panel data are used to do regression analysis. Second, this research does not include the effect of time (time effect) on the tax revenue in the model. However, the use of macroeconomic indicators such as; GDP Per-capita, inflation, and trade as control variables might accommodate the impact of shocks in the economy such as economic crises.

Future research is expected to examine the FDI at sector-level to find which sector has the most significant effect on tax revenue and its types. Future research could use a dynamic model or the application of lagged independent variables to extend the analysis of the effects of FDI.

The finding shows that the effect of FDI on tax revenue in developing countries is positive, but this effect tends to decrease along with the increase of GDP per-capita or FDI. Based on that finding, the policymaker in the developing countries supposed not only focus on how to attract as much as FDI inflow to the country, but should make sure that FDI will not erode tax revenue due to transfer pricing, massive tax incentives, and the uneven competition with domestic companies. The policies that can be formulated such as: inviting FDI for industries that do not erode the host country's main products, selection of FDI that does not harm the development of domestic industries due to monopolies and formulates enforceable policy on technology transfer. With these policies, the sustainability of tax revenue would be guaranteed.

In addition, since in developing countries the effect of greenfield FDI on total tax revenue is greater compared to brownfield FDI, policymakers should focus on inviting a new investor to establish a new company. By attracting greenfield FDI, tax revenue is expected to increase due to an increase in the number of taxpayers, an increase in the country's productivity, and a reduction in unemployment. On the other hand, in high-income countries, the policymakers should open more opportunities for mergers and acquisition (brownfield FDI) or forming joint ventures with foreign companies in order to increase productivity that finally will increase tax revenue. This method might be useful in reducing the cost of establishing new companies in high-income countries.

\section{REFERENCES}

Aitken, B.J. and A.E. Harrison (1999) 'Do Domestic Firms Benefit from Direct Foreign Investment? Evidence from Venezuela', American economic review 89(3): 605-618.

Almfraji, M.A. and M.K. Almsafir (2014) 'Foreign Direct Investment and Economic Growth 
Literature Review from 1994 to 2012', Procedia-Social and Behavioral Sciences 129: 206-213.

Aslam, A.M. (2015) 'A Case Study of Co integration Relationship between Tax Revenue and Foreign Direct Investment: Evidence from Sri Lanka', 2nd International Symposium, FIA, South Eastern University of Sri Lanka, pp251.

Augustine, N.Y. (2009) Erosion of the Property Tax Base: Trends, Causes, and Consequences. Lincoln Inst of Land Policy.

Balıkçıŏlu, E., B. Dalgıç and B. Fazlıoğlu (2016) 'Does Foreign Capital Increase Tax Revenue: The Turkish Case', International Journal of Economics and Financial Issues 6(2): 776781.

Bayar, Y. and O.F. Ozturk (2018) 'Impact of Foreign Direct Investment Inflows on Tax Revenues in OECD Countries: A Panel Cointegration and Causality Analysis.', Theoretical \& Applied Economics 25(1).

Bilquees, F. (2004) 'Elasticity and Buoyancy of the Tax System in Pakistan', The Pakistan Development Review 43(1): pp. 73-93.

Blalock, G. and P.J. Gertler (2005) 'Foreign Direct Investment and Externalities: The Case for Public Intervention', Does foreign direct investment promote development: 73-106.

Borensztein, E., J. De Gregorio and J. Lee (1998) 'How does Foreign Direct Investment Affect Economic Growth?', Journal of International Economics 45(1): 115-135.

Cassou, S.P. (1997) 'The Link between Tax Rates and Foreign Direct Investment', Applied Economics 29(10): 1295-1301.

Castro, G.Á. and D.B.R. Camarillo (2014) 'Determinants of Tax Revenue in OECD Countries Over the Period 2001-2011', Contaduría y administración 59(3): 35-59.

Chelliah, R.J., H.J. Baas and M.R. Kelly (1975) 'Tax Ratios and Tax Effort in Developing Countries, 1969-71', Staff papers 22(1): 187205.

Chu, M.K., M.H.R. Davoodi and M.S. Gupta (2000) 'Income Distribution and Tax and Government Social Spending Policies in Developing Countries', International Monetary Fund, Working Paper (0-62).
Demena, B. (2017) Essays on Intra-Industry Spillovers from FDI in Developing Countries: A Firm-Level Analysis with a Focus on SubSaharan Africa.

Demena, B.A. and van Bergeijk, P.A., 2019. Observing FDI spillover transmission channels: evidence from firms in Uganda. Third World Quarterly, pp.1-22.

Ebi, B.O. (2018) 'Financial Sector Development and Tax Revenue in Nigeria', International Journal of Economics, Commerce and Management VI (6): 93-109.

Friedman, E., S. Johnson, D. Kaufmann, and P. ZoidoLobaton (2000) 'Dodging the Grabbing Hand: The Determinants of Unofficial Activity in 69 Countries', Journal of public economics 76(3): 459-493.

Gaalya, M.S. (2015) 'Trade Liberalization and Tax Revenue Performance in Uganda', Modern Economy 6(02): 228.

Gropp, M.R. and M.K. Kostial (2000) The Disappearing Tax Base: Is Foreign Direct Investment (FDI) Eroding Corporate Income Taxes? International Monetary Fund.

Gupta, A.S. (2007) Determinants of Tax Revenue Efforts in Developing Countries. International Monetary Fund.

Holmes, T. J., McGrattan, E. R., \& Prescott, E. C. (2015). Quid Pro Quo: Technology Capital Transfers for Market Access in China. The Review of Economic Studies, 82(3), 1154-1193.

Huňady, J. and M. Orviská (2015) 'The Effect of Corruption on Tax Revenue in OECD and Latin America Countries', Theoretical and Practical Aspects of Public Finance 2015: 80.

Ilievski, B. (2015) 'Stock Markets and Tax Revenue', Journal of Applied Finance and Banking 5(3): 1-16.

Javorcik, B.S. and M. Spatareanu (2005) 'Disentangling FDI Spillover Effects: What do Firm Perceptions Tell Us?', Does foreign direct investment promote development: 4572 .

Jeza, M.T., A.A. Hassen and G. Ramakrishna (2016) 'The Impact of Foreign Direct Investment (Fdi) Flows on Aggregate and Disaggregate Tax Revenues in Ethiopia: A Bounds Test with a Structural Break', The Impact of Foreign Direct Investment (FDI) Flows o 16(2): 171-201. 
Leuthold, J.H. (1991) 'Tax Shares in Developing Economies a Panel Study', Journal of Development Economics 35(1): 173-185.

Lensink, R. and O. Morrissey (2001) Foreign direct investment: Flows, volatility, and growth in developing countries

Long, G. (2005) 'China's Policies on FDI: Review and Evaluation', Does foreign direct investment promote development: 315-336.

Lotz, J.R. and E.R. Morss (1967) 'Measuring "tax Effort" in Developing Countries', Staff Papers 14(3): 478-499.

MacDougall, G.D.A. (1960) 'The Benefits and Costs of Private Investment from Abroad: A Theoretical Approach 1', Bulletin of the Oxford University Institute of Economics \& Statistics 22(3): 189-211.

Mahmood, H. and A. Chaudhary (2013) 'Impact of FDI on Tax Revenue in Pakistan', Pakistan Journal of Commerce and Social Sciences 7(1): 59.

Nachrowi, D.N. and H. Usman (2006) Pendekatan Populer Dan Praktis Ekonometrika Untuk Analisis Ekonomi Dan Keuangan. Jakarta: Lembaga Penerbit Fakultas Ekonomi Universitas Indonesia.

Nguyen, H.T.T., M.H. Nguyen and A. Goenka (2014) 'How does FDI Affect Corporate Tax Revenue of the Host Country', Document De Recherche Epee, Centre D'etudes Des Politiques Economiques De L'universite D'evry, Retrieved August 10: 13-03.

Odabaş, H. (2016) 'Foreign Direct Investment Inflows on Tax Revenues in the Transition Economies of European Union', Global Journal on Humanities and Social Sciences 2(2): 17-22.

OECD (Last updated 2019a) 'Taxation'. Accessed may/28 2019 <https://stats.oecd.org>.

OECD (Last updated 2019b) 'Glossary of Foreign Direct Investment Terms and Definitions' (a webpage of OECD). Accessed May/25 2019 <https://www.oecd.org/daf/inv/investmen t-policy/2487495.pdf $>$

Romer, P.M. (1990) 'Endogenous Technological Change', Journal of political Economy 98(5, Part 2): S71-S102.

Rosid, A., C. Evans and B. Tran-Nam (2016) 'Do Perceptions of Corruption Influence
Personal Income Taxpayer Reporting Behaviour: Evidence from Indonesia', eJTR 14: 387.

Safitriani, S. (2014) 'Perdagangan Internasional Dan Foreign Direct Investment di Indonesia', Buletin Ilmiah Litbang Perdagangan 8(1): 93-116.

Solow, R.M. (1956) 'A Contribution to the Theory of Economic Growth', The quarterly journal of economics 70(1): 65-94.

Transparency International Organization (Last updated 2019) 'Corruption Perception Index'. Accessed May/26 2019 $<$ https://www.transparency.org/>.

UNCTAD (Last updated 2019) 'World Investment Report: Annex Tables' (a webpage of UNCTAD). Accessed May/26 2019 $<\underline{\text { www.unctad.org/fdistatistics }}>$.

UNCTAD (2018) 'World Investment Report'. New York and Geneva: United Nations Conference on Trade and Development.

UNCTAD (1999) 'World Investment Report: Foreign Direct Investment and The Challenge of Development', United Nations Conference on Trade and Development, United Nations Geneva.

UNCTAD (1996) 'World Investment Report: Investment, Trade and International Policy Arrangements', Foreign Trade Review 31(3): 85-109.

UNCTAD (2007) World Investment Report 2007: Transnational Corporations, Extractive Industries and Development. Switzerland: United Nations.

Wooldridge, J.M. (2015) Introductory Econometrics: A Modern Approach. Nelson Education.

World Bank (Last updated 2019a) 'Foreign Direct Investment, Net Inflows (\% of GDP)'. Accessed May/26 2019 <https://data.worldbank.org/indicator/BX. KLT.DINV.WD.GD.ZS>

World Bank (Last updated 2019b) 'GDP Per-Capita'. Accessed May/26 2019 <https://data.worldbank.org/indicator/NY. GDP.PCAP.PP.CD>.

World Bank (Last updated 2019c) 'Agriculture, Forestry, and Fishing, Value Added (\% of GDP)'. Accessed May/26 2019 
$<$ https://data.worldbank.org/indicator/NV. AGR.TOTL.ZS>.

World Bank (Last updated 2019d) 'Consumer Price Index $(2010=100)^{\prime}$. Accessed May/26 2019 <https://data.worldbank.org/indicator/FP. CPI.TOTL?end $=2018 \&$ start $=1960 \&$ view $=\mathrm{ch}$ art>.

World Bank (Last updated 2019e) 'Domestic Credit to Private Sector by Banks (\% of GDP)'. Accessed May/26 2019 <https://data.worldbank.org/indicator/FD. AST.PRVT.GD.ZS?locations=vn $>$.
Zeb, N., F. Qiang and M. Sharif (2014) 'Foreign Direct Investment and Unemployment Reduction in Pakistan', International Journal of Economics and Research 5(02): 10-17.

Zhu, Y. (2010) 'An Analysis on Technology Spillover Effect of Foreign Direct Investment and its Countermeasures', International Journal of Business and Management 5(4): 178. 


\section{APPENDIX}

Appendix 1 The coefficient of control variables (1)

\begin{tabular}{|c|c|c|c|c|c|c|}
\hline Group & No & $\begin{array}{l}\text { Dependent } \\
\text { Variables }\end{array}$ & Model & $\begin{array}{l}\ln \text { GDPPC } \\
\text { (GDP Per- } \\
\text { capita) }\end{array}$ & $\begin{array}{c}\text { CPI } \\
\text { (Corruption } \\
\text { Perception } \\
\text { Index) }\end{array}$ & $\begin{array}{l}\text { AGRI_GDP } \\
\text { (Share } \\
\text { Agriculture } \\
\text { In GDP) }\end{array}$ \\
\hline (1) & (2) & (3) & (4) & (5) & (6) & (7) \\
\hline \multirow{5}{*}{ 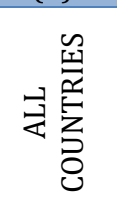 } & 1. & TAXREV_GDP & FEM & $1.898^{* * *}$ & $0.021^{*}$ & $-0.087^{* * *}$ \\
\hline & 2. & CORPTAX_GDP & FEM & $0.735^{* * *}$ & 0.008 & $-0.059^{* * *}$ \\
\hline & 3. & INDTAX_GDP & FEM & -0.122 & 0.004 & 0.002 \\
\hline & 4. & VAT_GDP & FEM & $0.673^{* * *}$ & $0.011^{* *}$ & $-0.031^{* * *}$ \\
\hline & 5. & PROPTAX_GDP & FEM & $0.419^{* * *}$ & $-0.017^{* * *}$ & -0.011 \\
\hline \multirow{5}{*}{ 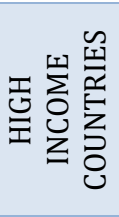 } & 1. & TAXREV_GDP & FEM & -0.745 & 0.014 & $-0.338^{* *}$ \\
\hline & 2. & CORPTAX_GDP & FEM & -0.318 & $0.020^{* * *}$ & $-0.345^{* * *}$ \\
\hline & 3. & INDTAX_GDP & FEM & $-1.090^{* * *}$ & 0.005 & 0.019 \\
\hline & 4. & VAT_GDP & FEM & $0.481^{* *}$ & $0.019^{* * *}$ & -0.042 \\
\hline & 5. & PROPTAX_GDP & FEM & $0.523^{* *}$ & $-0.024^{* * *}$ & -0.014 \\
\hline \multirow{5}{*}{ 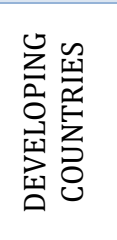 } & 1. & TAXREV_GDP & FEM & $4.384^{* * *}$ & 0.017 & $-0.122^{* * *}$ \\
\hline & 2. & CORPTAX_GDP & FEM & $1.976^{* * *}$ & $-0.021^{* *}$ & $-0.067^{* * *}$ \\
\hline & 3. & INDTAX_GDP & FEM & $0.458^{* * *}$ & -0.004 & -0.010 \\
\hline & 4. & VAT_GDP & FEM & $1.510^{* * *}$ & 0.004 & $-0.050^{* * *}$ \\
\hline & 5. & PROPTAX_GDP & FEM & $0.219^{* * *}$ & $-0.005^{* *}$ & -0.005 \\
\hline
\end{tabular}

*** $\mathrm{p}<0.01,{ }^{* *} \mathrm{p}<0.05, * \mathrm{p}<0.1$

Source: Author's calculation

Appendix 2 The coefficient of control variables (2)

\begin{tabular}{|c|c|c|c|c|c|c|}
\hline Group & No & $\begin{array}{c}\text { Dependent } \\
\text { Variables }\end{array}$ & Model & $\begin{array}{c}\text { TRADE } \\
\text { (International } \\
\text { Trade) }\end{array}$ & $\begin{array}{c}\text { INFL } \\
\text { (Inflation) }\end{array}$ & $\begin{array}{c}\text { PCB } \\
\text { (Private Sector } \\
\text { Credit per GDP) }\end{array}$ \\
\hline (1) & $(2)$ & (3) & (4) & (5) & (6) & (7) \\
\hline \multirow{5}{*}{ 蛋怘 } & 1. & TAXREV_GDP & FEM & 0.006 & $0.011^{* * *}$ & $-0.008^{* *}$ \\
\hline & 2. & CORPTAX_GDP & FEM & $0.004^{* *}$ & 0.000 & $-0.007^{* * *}$ \\
\hline & 3. & INDTAX_GDP & FEM & -0.002 & $0.006^{* * *}$ & -0.001 \\
\hline & 4. & VAT_GDP & FEM & 0.002 & $0.003^{* *}$ & -0.001 \\
\hline & 5. & PROPTAX_GDP & FEM & -0.000 & 0.001 & $-0.005^{* * *}$ \\
\hline \multirow{5}{*}{ 퐁 } & 1. & TAXREV_GDP & FEM & -0.008 & $0.027^{* * *}$ & $-0.010^{* * *}$ \\
\hline & 2. & CORPTAX_GDP & FEM & -0.001 & -0.005 & $-0.007^{* * *}$ \\
\hline & 3. & INDTAX_GDP & FEM & -0.001 & $0.016^{* * *}$ & -0.000 \\
\hline & 4. & VAT_GDP & FEM & -0.002 & 0.000 & 0.000 \\
\hline & 5. & PROPTAX_GDP & FEM & -0.003 & 0.003 & $-0.007^{* * *}$ \\
\hline \multirow{5}{*}{ 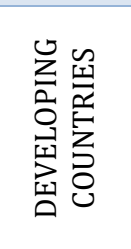 } & 1. & TAXREV_GDP & FEM & $0.052^{* * *}$ & -0.005 & $0.027^{* * *}$ \\
\hline & 2. & CORPTAX_GDP & FEM & $0.028^{* * *}$ & -0.003 & 0.007 \\
\hline & 3. & INDTAX_GDP & FEM & $0.003^{*}$ & 0.002 & $0.008^{* * *}$ \\
\hline & 4. & VAT_GDP & FEM & $0.012^{* * *}$ & -0.003 & -0.003 \\
\hline & 5. & PROPTAX_GDP & FEM & $0.001^{* *}$ & 0.001 & $-0.002^{* *}$ \\
\hline
\end{tabular}

*** $\mathrm{p}<0.01,{ }^{* *} \mathrm{p}<0.05,{ }^{*} \mathrm{p}<0.1$

Source: Author's calculation 